\title{
THE NATURE OF JUDICIAL INVOLVEMENT IN CIVIL PENALTY PROCEEDINGS TO EXECUTE FTC CEASE AND DESIST ORDERS
}

The division of responsibility among the Federal Trade Commission (FTC), the courts, and the jury in civil suits for violations of FTC cease and desist orders ${ }^{1}$ has been the subject of recent controversy. The problem arises because in combatting unfair or deceptive business practices $^{2}$ it may be necessary for the FTC to do more than issue a cease and desist order if it is to insure that such practices will be discontinued. ${ }^{3}$ An FTC order becomes final and effective either after the passing of a statutorily prescribed period of time ${ }^{4}$ or following enforcement by a circuit court of appeals; ${ }^{5}$ the Commission is then empowered to seek judicial sanctions to prevent further violations of its order. To this end, it may initiate a civil suit in district court for consumer redress, ${ }^{6}$ for equitable relief, or for statutorily prescribed civil

THE FOLLOWING CITATION WILL BE USED IN THIS NOTE:

J. Moore, Federal Practice (2d ed. 1966) [hereinafter cited as J. Moore].

1. These suits to enforce a penalty for violation of an order are brought pursuant to section 16 of the Federal Trade Commission Act (FTCA), Pub. L. No. 93-637, \& 204(a) (Jan. 4, 1975), amending 15 U.S.C.A. $\$ 56$ (Supp. 1974), reprinted in 4 TrADE REG. REP. IT $25,268$.

2. Whenever the Commission has "reason to believe" that an individual or business is using unfair methods of competition or unfair or deceptive practices in commerce, it may issue a complaint and hold hearings to determine whether a cease and desist order is justified. 15 U.S.C. $\$ 45$ (b) (1970) amended by Pub. L. No. 93-637, § 201(a) (Jan. 4, 1975), reprinted in 4 TRADE REG. REP. ITा 25,245-46.

3. A cease and desist order may be issued only after administrative hearings in which the accused party has the right to appear and offer evidence, and after written findings that the act or practice referred to in the coinplaint does, in fact, violate the statute. 15 U.S.C. $\$ 45(b)(1970)$.

4. The order will become final if an FTC cease and desist order is not appealed to the circuit court of appeals within the sixty day period allowed for filing a petition for review, id. $\$ 45(\mathrm{~g})(1)$; if the circuit court discusses the petition for review or affirms the order and no timely petition for certiorari is filed; or the petition is filed but denied, $i d . \S \S 45(\mathrm{~g})(2)-(3)$; or thirty days after the Supreme Court directs that the order be affirmed or the petition for review be dismissed, id. $\$ 45(\mathrm{~g})(4)$.

5. If an appeal is taken, it is conducted by a circuit court on the administrative record, with the Commission's findings deemed conclusive "if supported by the evidence." Id. $\$ 45(\mathrm{c})$. To the extent that the order is "enforced," the court issues its own decree commanding obedience, which may be executed in a contempt action. Id.

6. This consuiner redress remedy was recently added to the FTCA by Pub. L. No. 93-637, § 206(a) (Jan. 4, 1975), reprinted in 4 TraDE REG. REP. \I 25,271. 
penalties. ${ }^{7}$ When the FTC seeks to execute ${ }^{8}$ its order by suing for civil penalties, the Federal Trade Commission Act (FTCA) ${ }^{9}$ is uninstructive about the role that the district court should play-should it limit itself to a review of the FTC's administrative record, or should it grant the alleged violator a plenary trial? Recently, the Second Circuit Court of Appeals, in United States v. J.B. Williams Co., ${ }^{10}$

7. The means for imposing penalties for violations of FTC orders are provided by sections $5(l), 5(\mathrm{~m})$, and 16 of the FTCA. Subsection $5(l)$ provides im pertinent part: Any person, partnership, or corporation who violates an order of the Commission after it has become final, and while such order is in effect, shall forfeit and pay to the United States a civil penalty of not more than $\$ 10,000$ for each violation, which shall accrue to the United States and may be recovered in a civil action brought by the Attorney General of the Umited States. . . . In such actions, the United States district courts are empowered to grant mandatory injunctions and such other and further equitable rehef as they deem appropriate in the enforcement of such final orders of the Commission. 15 U.S.C.A. $\$ 45(l)(1974)$.

Subsection $5(\mathrm{~m})$ permits the FTC to:

. . . commence a civil action to obtain a civil penalty in a district court . . . against any person, partnership, or corporation which engaged im [an] act or practice [prohibited by a cease and desist order,] -

(1) after such cease and desist order becomes final (whether or not such person ... . was subject to such . . . order), and

(2) with actual knowledge that such act or practice is unfair or deceptive and is unlawful [under the Act]. Pub. L. No. 93-637, \& 204(b) (Jan. 4, 1975), amending 15 U.S.C.A. $\& 45(\mathrm{~m})(1)(\mathrm{B})$ (Supp. 1974), reprinted in 4 TRADE REG. REP. $\int 25,256$ A.

Section 16 allows the Commission to commence and supervise the litigation of civil penalty suits by its own attorneys if the Attorney General, upon request, fails to bring action within forty-five days. Pub. L. No. 93-637, § 204(a) (Jan. 4, 1975), amending 15 U.S.C.A. $\$ 56$ (Supp. 1974), reprinted in 4 TRADE REG. REP. \ 25,268.

Although not expressly provided for in the statute, a contempt remedy is also available to the FTC if its order has been previously affirmed on appeal by a circuit court. See United States v. Morton Salt Co., 338 U.S. 632, 639 (1950). The court, in such a case, acts to penalize violations of its own decree issued in support of the agency order. See 15 U.S.C. \& 45(c) (1970).

8. See generally Parker, The Execution of Administrative Acts, 24 U. Crr. L. REv. 292 (1957). Such execution actions should be distinguished from enforcement actions. Narrowly defined and as used in this Note, an enforcement action will refer to that process in which a party against whom an administrative order has been issued seeks review of that order in a circuit court of appeals before it becomes effective. See FTCA $\S$ 5(g)-(i), 15 U.S.C. $\S \S 45(\mathrm{~g})$-(i) (1970); National Labor Relations Act $\$ 10(\mathrm{e}), 29$ U.S.C. $\$ 160$ (e) (1970). By contrast, an execution action is subsequent to such an enforcement action or a statutory period of time after which an administrative order becomes "final." An execution action is a civil suit initiated by the agency in a district court for the alleged violation of its order. The focus of that suit is the determination of whether the order has been violated and sanctions should be imposed. See FTCA $\S \S 5(l),(\mathrm{m}), 16$, Pub. L. No. 93-637, $\$$ 204(a), (b) (Jan. 4, 1975), amending 15 U.S.C.A. $\$ \S 45(l),(\mathrm{m}), 56$ (Supp. 1974), reprinted in 4 TRADE REG. REP. IIT 25,256A, 25,268 .

9. Pub. L. No. 93-637 (Jan. 4, 1975), amending 15 U.S.C.A. $\$ \$ 45(l),(\mathrm{m}), 56$ (Supp. 1974), amending 14 U.S.C. $\S \S 41$ et seq. (1970), reprinted in 4 TRADE REG. REP. $\{$ 25,240-73.

10. 498 F.2d 414 (2d Cir. 1974), aff'g in part, rev'g in part 354 F. Supp. 521 (S.D.N,Y. 1973), 
responded to this question by requiring that the alleged violator be accorded a plenary trial as well as the right to have disputed issues of fact decided by a jury.

After briefly discussing the facts and holding of the Williams case, this Note will consider the nature of an action to impose a civil penalty (referred to as an execution of the order) and analyze the Williams court's response to the question of the proper level of judicial involvement in this proceeding. Concluding that a suit for violation of a cease and desist order should be a plenary proceeding, this Note will then examine the question of what issues the finder of fact should consider and what standards should guide a court in determining whether suminary judgment is appropriate. Finally, the right of an accused violator to a jury trial in civil penalty proceedings will be analyzed.

The Williams case grew out of a long-standing dispute between the FTC and the J.B. Williams Co. over the content of the latter's advertisements for its proprietary drug products, Geritol and FemIron. ${ }^{11}$ After extensive administrative ${ }^{12}$ and judicial proceedings ${ }^{13}$ surrounding the issuance and judicial enforcenent of a cease and desist order, and lengthy efforts to obtain voluntary compliance with what it conceived to be the requirements of that order, ${ }^{14}$ the FTC initiated a civil penalty

11. As early as 1962, the FTC had objected to representations by J.B. Williams and its advertising subsidiary, Parkson, that Geritol was an effective general remedy for tiredness and loss of strength. Government investigations had indicated that the preparation relieved such conditions only when they were caused by a deficiency of iron in the bloodstream and that feelings of tiredness in the great majority of persons are not attributable to such a deficiency. See 498 F.2d at 418 .

12. Between 1962 and 1965 , the FTC engaged in negotiations with J.B. Williams representatives and conducted formal evidentiary hearings which led eventually to the issuance of a cease and desist order. The order, in general, prohibited the dissemination of any advertisement which represented, either directly or by implication, that the use of Geritol or any substantially similar composition would relieve tiredness without a corresponding disclosure that such relief could be anticipated in only the small minority of cases where tiredness was caused by an iron and vitamin deficiency. See FTC Cease and Desist Order, November 27, 1967, quoted in United States v. J.B. Williams Co., Inc., 354 F. Supp. 521, 526 (S.D.N.Y. 1973), aff'd in part, rev'd in part, 498 F.2d 414 (2d Cir. 1974).

13. After the order was issued, J.B. Williams exercised its tight under section 5(c) of the FTCA, 15 U.S.C. $\$ 45(\mathrm{c})$ (1970), to secure judicial review in the circuit court. The Sixth Circuit affirmed the order with minor modifications and promulgated its own enforcement decree. See J.B. Williams Co., Inc., v. FTC, 381 F.2d 884 (6th Cir. 1967).

14. During 1968-69, the FTC reviewed a series of compliance reports filed by J.B. Williams, held public hearings on compliance, and negotiated further with J.B. Williams and Parkson in an attempt to reach agreement on acceptable advertising. But, despite the deletion of direct references to tiredness and the insertion of disclaimers, the agency found that Geritol television commercials still implied that the product was an effective remedy for tiredness, in violation of its order. See FTC Opinion, December 2, 1968, and FTC formal statement, June 25, 1969, both discussed in United States v. J.B. Wil- 
action for violation of its order, seeking penalties of $\$ 500,000$ from both Williams and its advertising subsidiary, Parkson. ${ }^{15}$ In eleven counts the government charged the defendants with one hundred separate infractions of the final FTC order. ${ }^{16}$

Although in the district court the defendants contended that there were disputed issues of material fact ${ }^{17}$ and demanded a jury trial, summary judgment was granted fon the government on all counts and

liams Co., Inc., 498 F.2d 414, 419-20 \& n.5 (2d Cir. 1974). Moreover, by mid-1969, J.B. Williams had begun disseminating similar advertising for a new iron preparation called FemIron, which the FTC concluded had properties substantially similar to Geritol and thus was covered by the proscriptions of the same order. See FTC letter, September 3, 1969, cited in United States v. J.B. Williams Co., Inc., 498 F.2d 414, 420 (2d Cir. 1974), and Brief for Appellee at 7, United States v. J.B. Williams Co., Inc., 498 F.2d 414 (2d Cir. 1974), in which the Commission rejected a complance report filed by J.B. Williams, in part because it did not include data on FemIron commercials.

15. See United States v. J.B. Williams Co., Inc., 354 F. Supp. 521, 526 (S.D.N.Y. 1973), aff'd in part, rev'd in part, 498 F.2d 414 (2d Cir. 1974). The Commission proceeded under section 16 of the FTCA, 15 U.S.C.A. $\$ 56$ (Supp. 1974), amended, Pub. L. No. 93-637, § 204(a) (Jan. 4, 1975), certifying to the Attorney General the facts which it had reason to believe constituted a violation of its order and recommending to him that civil penalty proceedings be brought in district court as authorized by section $5(l)$. The Attorney General subsequently filed the complaint.

Section 16 has since been amended to allow the Commission to initiate and supervise the litigation itself if the Attorney General declines to file the complaint as requested, See Pub. L. No. 93-637, § 204(a) (Jan. 4, 1975), amending 15 U.S.C.A. § 56 (Supp. 1974), reprinted in 4 TRADE REG. REP. \ 25,268.

16. The alleged violations were of three different types. Counts one through four related to the use of a series of Geritol commercials that emphasized the product's "blood building power" and its capacity to build "iron power in your blood fast." 498 F,2d at 419-20. The Commission had formally advised Williams before the broadcast of these commercials that it considered use of the word "power" to be in violation of the order because, im its judgment, it implied relief from tiredness. See FTC formal statement, June 25, 1969, supra note 14.

Counts five through nine dealt with a different series of Geritol commercials which depicted a woman as "sad" (and apparently tired) before taking Geritol, and "glad" (and apparently vigorous) afterwards. Again, the Commission concluded that the advertising conveyed the impermissible implication. See FTC letter, Sept. 3, 1969, supra note 14.

Counts ten and eleven concerned the airing of commercials for FemIron, a new product not expressly named by the cease and desist order, but which the agency judged to have properties substantially similar to Geritol. That being the case, the FTC concluded that FemIron was subject to the Geritol order which encompassed "any other preparation of substantially similar composition or possessing substantially similar properties, under whatever name or names sold," and that the advertising done to promote it failcd to comply with the order's requirements. See 498 F.2d at 420 .

17. The defendants admitted disseminating the commercials in question, but argued that there were two factual issues presented in this regard: (1) whether the commercials actually implied a remedy for tiredness so as to be prohibited by the cease and desist order, and (2) whether FemIron was a product so similar to Geritol as to be within the reach of the same order. See United States v, J.B. Williams Co., Inc., 354 F. Supp. 521, 531-33 (S.D.N.Y. 1973), aff'd in part, rev'd in part, 498 F.2d 414 (2d Cir. 1974). 
penalties were assessed totalling $\$ 812,000 .^{18}$ On appeal, the Second Circuit found that triable issues of fact were presented and that summary judgment was improper for most counts. ${ }^{19}$ It then concluded that on those counts where summary judgment was not appropriate, the defendants had the right to a jury trial. ${ }^{20}$

\section{Civil Penalty Proceeding to Execute an FTC Cease and DEsist ORDER-Plenary TRIAL OR JUdICIAL REVIEW?}

While some agencies are given the power to enforce their own orders, ${ }^{21}$ the imposition of sanctions is generally accompanied by at least a subsequent judicial review. ${ }^{22}$ Unless otherwise provided, this review is conducted on the record of agency proceedings, and the court upholds the administrative order if it is supported by "substantial evidence."23 However, the FTCA, along with numerous other stat-

18. 354 F. Supp. at 527,533 . The court declined to impose the then maximum penalty of $\$ 5,000$ for each violation, finding some incidents less egregious than others and levying generally smaller penalties on Parkson than on Williams because it was "a sunaller colnpany." Id. at 549, 552-53.

19. United States v. J.B. Williams Co., Inc., 498 F.2d 414, 430-34 (2d Cir. 1974). The majority found that, as to counts one through nine, the question of whether the commercials conveyed the implications forbidden by the order was sufficiently disputed to demand a trial on the evidence. It agreed, however, with the lower court's judginent as to the "substantially similar" properties of FemIron, finding that the defendant's affidavits were totally ineffective in contradicting government evidence, and affirmed the summary judginent on counts ten and eleven because the FemIron commercials plainly implied that the product was an effective remedy for tiredness and anemia. Id.

20. Id. at 430 .

21. This power is common where the agency issues a negative order simply denying a requested action, claim, or privilege. Such orders need no further enforceinent and are effective until set aside. Examples might include the denial of social security benefits or the refusal to grant a license or passport.

Such authority inay extend to affirmative actions as well, particularly emergency measures such as the seizure of unliealthy or falsely labeled food. See Ewing v. Mytinger \& Casselberry, Inc., 339 U.S. 594 (1950). And, in some cases, Congress has granted admimistrative agencies the power to impose statutory civil penalties for what they judge to be violations of the law without first referring the matter to the courts. See, e.g., Marine Mammal Protection Act, 16 U.S.C.A. \& 1375(a) (1974); Occupational Safety and Health Act, 29 U.S.C. \& 666 (1970); Natural Gas Pipeline Safety Act, 49 U.S.C. $\$ 1678$ (1970). This legislative delegation of quasi-judicial power has been upheld by the courts where the penalty proceedings are neither criminal nor in the nature of a suit at common law. See Lloyd Sabando Societa v. Elting, 287 U.S. 329, 335 (1932); Oceanic Steam Navigation Co. v. Stranahan, 214 U.S. 320 (1909). As to the right of jury trial in this context, see text accompanying notes 106-17 infra.

22. See K. Davis, Administrative Law Text $\$ 23.05$, at 446 (3d ed. 1972); L. JAFFE 261. The Administrative Procedure Act (APA) ch. 7, 5 U.S.C. $\$ \$ 701$ et seq. (1970), inakes all "final agency actions subject to judicial review unless such review is precluded by statute or the action is committed to agency discretion by law."

23. See APA $\S 706,5$ U.S.C. $\$ 706(2)(E)(1970)$. If the agency is not required 
utes, requires that any agency decision to assess a penalty for violation of an administrative order be executed only by the courts, i.e., that judicial action precede the imposition of sanctions. ${ }^{24}$

Despite this necessity for judicial execution and the corresponding absence of any agency determination capable of directly affecting a private party, ${ }^{25}$ Judge Oakes, in his Williams dissent, argued that the civil penalty action under the FTCA is a form of judicial review. ${ }^{26}$ Relying heavily upon the extensive FTC proceedings conducted before the FTC brought the execution action against J.B. Williams, ${ }^{27}$ Judge Oakes would have instructed the district court to give "great deference" to the Commission's conclusion that its order had been violated. ${ }^{28}$ The Williams majority, however, decided that a plenary trial, without deference to the FTC's findings, was the proper approach. ${ }^{29}$

The inajority's conclusion finds support in the language of the statute itself. The FTCA provides for execution of agency orders by means of an FTC-imitiated suit in district court for civil penalties. ${ }^{30}$ Such a provision is difficult to read as requiring no more than judicial review of the administrative record. Had Congress intended to restrict the role of the courts in suits for violations of an FTC order, it could easily have desiguated the action as "review" or indicated that the "substantial evidence" standard should apply, as it did in another FTCA provision. ${ }^{31}$ Neither the legislative history of the FTCA $^{32}$ nor the rele-

to hold a hearing on the record before acting or to make formal findings, the appropriate standard for review is whether its action was "arbitrary" or "capricious." Id. \& 706(2) (A). See Camp v. Pitts, 411 U.S. 138 (1973).

24. In addition to the FTCA $\S 5(l), 15$ U.S.C.A. $\S 45(l)$ (Supp. 1974) (quoted in note 7 supra), see Packers and Stockyards Act, 7 U.S.C. \$ 207(g) (1970); Banking Act of 1933, 12 U.S.C. $\$ 335$ (1970); Clayton Act, 15 U.S.C. $\$ 21(l)(1970)$; Securities Exchange Act, 15 U.S.C. $\$ 78 \mathrm{ff}(\mathrm{b})$ (1970); Federal Communications Act of 1934, 47 U.S.C. $\S \S 503(b)(1)$, 504(a) (1970); Federal Aviation Act, 49 U.S.C. $\$ 1471$ (1970).

25. See text accompanying note 39 infra.

26. See 498 F.2d at $449,454-55$.

27. Id. at 439,454 . The dissent notes that "[t]hese proceedings during the 'compliance' phase consisted of public hearings, findings of the FTC, correspondence, meetings between representatives of the FTC and appellants, and the certification of facts by the FTC to the Attorney General along with transmittal of a draft complaint." Id. at 454 .

28. Id.

29. Id. at 422, 429-30. Judge Friendly, writing for the majority, spoke of "plenary powers of adjudication as distinguished from review of administrative action." Id. at 422.

30. FTCA $\$ 5(l), 15$ U.S.C.A. $\$ 45(l)$ (Supp. 1974).

31. See FTCA \& 5(c), 15 U.S.C. \& 45(c) (1970).

32. See United States v. J.B. Wilhams Co., Inc., 498 F.2d 414, $425-27$ (2d Cir, 1974). But sęe id. att 446̧-48 (Oakes, J., dissenting). 
vant statutory language indicates that a court should defer to the FTC's assertion that its order has been violated. ${ }^{33}$ Moreover, in other contexts a civil penalty suit traditionally has been thought to entail a plenary trial. $^{34}$

Although the language of the FTCA does not explicitly preclude an interpretation that the civil penalty proceeding is to be a form of judicial review, such a reading is questionable for other reasons. The judicial review position rests on an interpretation of the FTC's decision to initiate civil penalty proceedings as a dispositive agency determination that its order has been violated. ${ }^{35}$ The judicial action is viewed

33. The newly enacted section 19 of the FTCA, Pub. L. No. 93-637, $\$ 206$ (a) (Jan. $4,1975)$, reprinted in 4 TRADE REG. REP. I 25,271, which permits the Commission to seek compensation for injured consumers might seem to belie this statement. It provides that in judicial actions to impose such remedies for violation of a cease and desist order, "the findings of the Commission as to the material facts in the proceeding under section 5(b) with respect to [the alleged offender's] . . . act or practice, shall be conclusive ...." In fact, there is no inconsistency. The findings treated as conclusive are only those of the section $5(\mathrm{~b})$ hearings, which concluded that the statute was being violated and that a cease and desist order was appropriate. See notes 2-3 supra and accompanying text. These findings must be distinguished from the agency's subsequent determination that its order, once it has become final, was being violated and that such violations justified the seeking of statutory penalties in a district court. The courts have agreed, even prior to the amendment, that the section $5(\mathrm{~b})$ findings as to the appropriateness of a cease and desist order are conclusive in subsequent penalty proceedings. See note 58 infra. But there is no suggestion that the courts may not independently examine the facts of alleged violations even though the validity of the underlying order may not be relitigated. See note 8 supra for the distinction between judicial review and judicial execution proceedings.

The same general reasoning applies to section $5(\mathrm{~m})(2)$ of the FTCA, Pub. L. No. 93-637, § 204(b) (Ian. 4, 1975), reprinted in 4 TRADE REG. REP. If 25,256A, which provides that where a cease and desist order is executed by assessment of civil penalties against a party other than the party for whom the order was originally issued, "the issues of fact . . . against such defendant shall be tried de novo." This might imply that, as to those defendants against whom the original cease and desist order was issued, the penalty proceedings should be in the nature of judicial review. The apparent purpose of this provision, however, is simply to guarantee to the special class of defendants against whom the original order was not issued but who are charged with knowledge of the conduct it prohibits at least one opportunity to contest the order they are being charged with violating. The "issues of fact" to be tried de novo must then be those issues that would have been decided in the section 5 (b) proceedings if those proceedings had originally been brought against this special class of defendants. This statutory guarantee is necessary because a party against whom an order has been directed may not relitigate the validity of the order in subsequent penalty proceedings. Thus, section $5(\mathrm{~m})(2)$ would seem to carry no negative implication as to the nature of review to be accorded the evidence of violations of such orders.

34. See United States v. Regan, 232 U.S. 37 (1914); Hepner v. United States, 213 U.S. 103 (1909), both recognizing a right to jury trial and, therefore, plenary proceedings in civil penalty suits. See note 95 infra and accompanying text. See also United States v. J.B. Williams Co., Inc., 498 F.2d 414, 422-24 (2d Cir. 1974).

35. 498 F.2d at 444 (Oakes, J., dissenting). Judge Oakes argued that "once an 
not as an independent civil action but rather as an inextricable and final stage of the administrative regulatory scheme. ${ }^{30}$ If this is true, the court's role would be the same as that recently ascribed to it by the Supreme Court in a wholly different context-to review agency-enforceable decisions ${ }^{37}$ upon the administrative record. ${ }^{38}$ However, the FTC's decision to bring a statutory penalty suit is strictly informal, $e x$ parte, and totally dependent on the courts for effect. It is hittle different from a government prosecutor's decision to bring criminal charges for suspected illegal activity-a decision clearly entitled to no particular weight of its own at the trial. The agency makes no conclusive determination of guilt or innocence; its role in the execution process is confined to initiating proceedings when it has reason to beheve that its orders may have been violated. ${ }^{39}$ The district court cannot sit to review an effective agency decision for, indeed, there has been none. It can only conduct appropriate proceedings to consider de novo whether, on the basis of evidence submitted at trial, a violation has occurred. ${ }^{40}$

order of the FTC is final, one subject to such an order has already had his 'day in court' and is on notice thereafter that violations are subject to severe penalties without the interposition of renewed hearings and trials of issues that have been previously decided." Id. at 449 (einphasis deleted).

36. Id. at 440,453 .

37. See note 21 supra and accompanying text.

38. See Camp v. Pitts, 411 U.S. 138 (1973). Camp dealt with judicial review under the APA, 5 U.S.C. $\$ \$ 701$ et seq. (1970), of a decision made by the Comptroller of the Currency without hearings or formal findings to deny an application for a national bank charter. The Court ruled that de novo hearings were inappropriate and that review of the informal findings must be conducted according to the arbitrary and capricious standard of the APA, id. $\$ 706(2)(A)$. 411 U.S. at 140-42. Iu Camp, however, there was no statute requiring that the administrative decision be executed by a court. On the contrary, the Comptroller's determination was fully effective, without further action, unless and until overturned on review.

39. See FTCA $\S 5(\mathrm{~m})(1)(A)$, Pub. L. No. 93-637, $\S 204(\mathrm{~b})$ (Jan. 4, 1975), amending 15 U.S.C.A. \$ 45(m)(1)(A) (Supp. 1974), reprinted in 4 TRADE REG. REP. II 25,256A (quoted in note 7 supra).

40. Neither chapter 7 of the APA, 5 U.S.C. $\$ \$ 701$ et seq. (1970), nor Camp v. Pitts, 411 U.S. 138 (1973), see note 38 supra, suggest a different result. Section 706(2) of the APA provides that "[t]he reviewing court shall . . . set aside agency action, findings, and conclusions found to be . . . unwarranted by the facts to the extent that the facts are subject to trial de novo by the reviewing court." 5 U.S.C. $\$ 706(1970)$ (emplasis added). The Supreme Court in Camp recognized that such "de novo review is appropriate only where there are imadequate fact-finding procedures in an adjudicatory proceeding or where judicial proceedings are brought to enforce certain administrative actions." 411 U.S. at 142, citing Citizens to Preserve Overton Park v. Volpe, 401 U.S. 402,415 (1971). Overton Park did not expressly require de novo review in all judicial enforcement actions, but only where the agency adjudicatory fact-finding procedures are inadequate or where issues are raised which were not before the agency. Nevertheless, it is significant that the Court in Camp subsequently interpreted its holding in Overton 
United States v. H.M. Prince Textiles, Inc., ${ }^{41}$ one of the few cases to examine the execution procedures of the FTCA, in effect gave the defendant a plenary trial even though none had been requested. The defendant textile company was alleged to have violated a cease and desist order proscribing the mislabeling of defendant's textiles as to fiber content. The court exhaustively examined the evidence of mislabeling and reached an independent conclusion that there had been a violation. ${ }^{42}$

Civil penalty provisions under other federal regulatory acts also have been interpreted as requiring a trial de novo. ${ }^{43}$ Suits to compel obedience to the orders of the Interstate Commerce Commission ${ }^{44}$ and

Park to mean that de novo review is appropriate whenever judicial proceedings are brought to enforce certain administrative actions. 411 U.S. at 142.

41. 262 F. Supp. 383 (S.D.N.Y. 1966).

42. Id. at 388. The Williams court cited the recent case of United States v. Beatrice Foods Co., 344 F. Supp. 104, 111 (D. Minn. 1972), aff'd, 493 F.2d 1259 (8th Cir. 1974), as lending support to the plenary trial theory. 498 F.2d at 428 . In Beatrice Foods, the court granted summary judginent on the government's contentions that an FTC order had been violated, but Judge Neville implied in dictum that if the defendant had been able to establish issues of material fact, he would then have been entitled to a jury trial in civil penalty proceedings, under either the FTCA or the Clayton Act. 344 F. Supp. at 111; cf. FTC v. Sterling Drug Co., 317 F.2d 669 (2d Cir. 1963) (trial de novo required where FTC sues to enjoin deceptive advertising under section 13(a) of the FTCA).

Several similar cases have been cited in support of the contrary proposition that civil penalty actions do not require plenary proceedings. See, e.g., United States v. Vulcanized Rubber \& Plastics Co., 178 F. Supp. 723 (E.D. Pa. 1959), affd, 288 F.2d 257 (3d Cir.), cert. denied, 368 U.S. 821 (1961) (agency order prohibiting representation that coinbs were inade of rubber violated by labeling thein "rubber-resin"); United States v. Piuma, 40 F. Supp. 119 (S.D. Cal. 1941), aff'd, 126 F.2d 601 (9th Cir.), cert. denied, 317 U.S. 637 (1942) (agency order prohibiting representation of product as a "gland tonic" violated by advertisement of it as a "gland tablet"). In these cases the government was awarded sumnary judgment. However, they do not suggest that a plenary trial is inappropriate in all civil penalty suits; they inerely hold that one is not required where there are no disputed issues of material fact. In both Vulcanized and Piuma, the defendants did nothing to materially change their deceptive representations, so they had no grounds for arguing that their conduct was not proscribed by the agency's orders. See notes 78, 100 infra and accompanying text for further discussion of these cases.

43. At least one statute, the Federal Commumications Act, 47 U.S.C. $\$ \S 503-04$ (1970), expressly stipulates that recovery of civil forfeitures shall be by means of a trial de novo. The FCC must give an accused violator a written notice of "apparent liability," making what Professor Jaffe has described as a "semi-formal though legally inconclusive adjudication." L. JAFFE 113 .

44. See ICC v. Cincinnati, N.O. \& T.P. Ry., 56 F. 925, 934-35 (C.C.N.D. Ga. 1893), aff' $d, 162$ U.S. 184 (1896), an action brought under 49 U.S.C. $\$ 16(12)$ (1970) to execute an order of the I.C.C. The court rejected the idea that a federal court is confined to the "ministerial duty" of affirming and implementing agency orders and insisted upon an original, independent action in which the questions at issue are tried and determined de novo. See also Baer Bros. Mercantile Co. v. Denver R.G.R.R., 200 F. 
condemnation actions brought by the Food and Drug Administration ${ }^{45}$ have both been treated as independent plenary proceedings in which the agencies' determinations are entitled to no special weight. And, in suits to recover statutory penalties imposed by such diverse statutes as the Safety Appliance Act ${ }^{46}$ and the Agricultural Adjustment Act $^{47}$ for the violation of administrative orders, the result has been the same.

Where contempt proceedings are available to impose sanctions for the violation of an agency order-an execution procedure coinparable to the civil penalty suit ${ }^{48}-$ a plenary trial is clearly required. ${ }^{49}$ The decisions suggest that in such actions the heavy burden of proving contempt is on the agency ${ }^{50}$ and the evidence inust be clear and convincing. ${ }^{51}$ Once a judicial enforcement decree is entered affirming the

614 (D. Colo. 1912); Kentucky \& I. Bridge Co. v. Louisville \& N.R.R., 37 F. 567, 614 (C.C.D. Ky. 1889).

45. See United States v. 95 Barrels of Vinegar, 265 U.S. 438 (1924), a case brought under section 10 of the Food and Drug Act of 1906, 34 Stat. 768, as amended, 21 U.S.C. $\S 334$ (1970), for alleged mislabeling of a food product. The district court upon trial, and both the circuit court and the Supreme Court on appeal, engaged in full consideration of the factual issue of whether vinegar made froin dehydrated apples could properly be labeled "apple cider vinegar." None of the courts deferred to the Food and Drug Administration's conclusion that such labelimg was misleading.

46. 45 U.S.C. § 6 (1970); cf. United States v. Chicago, B. \& Q.R.R., 199 F.2d 223 (7th Cir. 1952), cert. denied, 345 U.S. 908 (1953) (de novo review conducted to determine if defendant's operations were subject to the requirements of an I.C.C. safety order).

47. 7 U.S.C. $\S \S 1314,1376$ (1970). See United States v. Lynn, 132 F. Supp. 605 (E.D. Ky. 1955) (government must prove in plenary proceedings that defendant exceeded his tobacco acreage allotment before civil penalties will be inposed).

48. There would appear to be little reason for differentiating between the nature of judicial action appropriate for civil contempt proceedings and that appropriate for civil penalty actions. Both serve the sane purpose: the judicial imposition of sanctions for the violation of administrative orders. Indeed, Professor Jaffe has equated the two, noting: "At the stage where a violation is being tried, the court, at least in form, is an original deciding body. .... [O]nce a court is engaged in imposing a sanction, ... [it] is in ultimate control." L. JAFFE 266-67. Professor Parker agrees that the court's decision in this context "is not a mere implementation of the administrative action but rather amounts to the final decision." Parker, supra note 8, at 310 .

49. See, e.g., NLRB v. Dell, 309 F.2d 867 (5th Cir. 1962), cited in United States v. J.B. Williams Co., Inc., 498 F.2d 414, 429 (2d Cir. 1974). In Dell, the Fifth Circuit held that where the Labor Board's contempt charges are disputed, the burden is on the government to prove the facts of violation that would justify a contenpt judgment. The district court, it said, nuust be prepared to conduct a plenary trial considering evidence submitted by the parties. 309 F.2d at 869 .

Another circuit court has declared that "[t]he interposition of the judiciary as the enforcing agency must have some meaning. ... . The [agency] was not given enforcement power; that power was lodged in the courts as a judicial function. Its exercise is not merely mechanical." NLRB v. Eanet, 179 F.2d 15, 21 (D.C. Cir. 1949); accord, NLRB v. Kingston Cake Co., 206 F.2d 604, 611 (3d Cir. 1953). See L. JAFFE 305.

50. See Kansas City Power \& Light Co. v. NLRB, 137 F.2d 77, 79 (8th Cir. 1943).

51. See NLRB v. Tupelo Garment Co., 122 F.2d 603, 606 (5th Cir. 1941). The 
agency order, "further questions as to the reach of the decree are properly within the exclusive control of the enforcing court." ${ }^{\text {252 }}$

\section{What the Fact-Finder Decides}

The foregoing discussion does not, of course, answer the question of whether a plenary trial in an execution action results in an unacceptable degree of interference with the proper functioning of administrative agencies. Judge Oakes, in his Williams dissent, contended that to allow a court or jury to determine whether a particular advertisement violates an FTC cease and desist order is to strip the Commission of its responsibility for deciding what constitutes deceptive advertising. ${ }^{53}$ In his view, the lower court in Williams was being directed on remand

substantial evidence rule is inapplicable in civil contempt proceedings. See NLRB v. Retail Clerks Int'l Ass'n, 203 F.2d 165 (9th Cir. 1953), adhered to on rehearing, 211 F.2d 759 (1954).

52. L. JAFFE 305.

53. 498 F.2d at $440-41$ n.4. A series of relatively recent decisions considering the proper role of the FTC in enforcing its orders might, at first glance, appear to strengthen this argument. Language in both United States v. St. Regis Paper Co., 355 F.2d 688 (2d Cir. 1966), and Holloway v. Bristol-Myers Corp., 485 F.2d 986 (D.C. Cir. 1973), can be read to grant the Commission virtually exclusive authority to determine violations of its own orders. $355 \mathrm{~F} .2 \mathrm{~d}$ at $693 ; 485 \mathrm{~F} .2 \mathrm{~d}$ at 1002 . These decisions, however, must be considered in the contexts in which they arose. Although both were attempts to secure civil penalties under the provisions of the FTCA, neither action was initiated by the FTC and neither considered the division of authority between the agency and the courts. In St. Regis, the issue was whether the Attorney General could bring a penalty action on his own initiative without the FTC's certifying the facts of a suspected violation of its orders under section 16 of the FTCA. In Holloway, the question was whether private parties have a right of action to enforce provisions of the FTCA. Both courts held that the power to commence civil penalty suits was vested exclnsively in the FTC. But it must be stressed that these courts considered only the agency's competence to make the initial decision as to coinpliance, i.e., whether to initiate civil execution action, and not its competence to reach a definitive decision as to an advertiser's liability for statutory penalties. Neither court suggested that the FTC's preliminary determination of a possible violation was entitled to any special weight in the trial itself. FTC v. Colgate-Palmolive Co., 380 U.S. 374 (1965), is a third decision sometimes cited in support of the interference argument. In reviewing on appeal a circuit cont decision not to enforce an FTC cease and desist order, the Supreme Court observed that "the Commission is often in a better position than are courts to determine when a practice is 'deceptive," and that its "judginent is to be given great weight by reviewing courts." Id. at 385. While the issue in the Colgate case was more clearly drawn between the agency and the court than it was in St. Regis or Holloway, the opinion is likewise inapposite. The case dealt solely with judicial review of an agency order by the court of appeals under section $5(\mathrm{c})$ of the FTCA-a much different proceeding than a civil penalty action under section $5(l)$. See note 8 supra. Not only are the standards of review different (substantial evidence as opposed to trial de novo), but also the issue examined is different. In the review proceeding, the court is concerned only with the general validity of the agency order; iu the penalty action, its duty is to determine the fact of violation. 
to decide "whether specific advertisements [were] deceptive under the [FTCA]," $"$ a task only the agency was qualified to perform. "[The majority's] substitution of judicial judgment for that exercise of administrative expertise," said Oakes, "is unsupportable."

While this argument has considerable force in the context of a judicial enforcement proceeding, ${ }^{56}$ it misconceives the issue before the court in a civil penalty suit. In an execution action, the sole question for the finder of fact is whether the conduct in issue can fairly be said to be that proscribed by the agency's cease and desist order, ${ }^{57}$ not whether that conduct is unfair or deceptive; the latter determination is made by the FTC im its cease and desist order proceedings and is reviewable only in a judicial enforcement action. ${ }^{58}$ For example, in the Williams case, the only question to be determined by the fact-finder was whether an advertisement claiming that Geritol "builds iron in your blood" was within the class of representations forbidden by the FTC's prior cease and desist order which forbade any future Geritol advertisement "which represents directly or by implication that the use of such preparation will be beneficial in the treatment or rehef of tiredness, loss of strength, rundown feeling, nervousness or irritability .....958

Thus, the issue to be decided in a plenary trial for execution of an administrative order has a limited scope. The fact-finder does not interfere with the FTC's sole authority to determine initially what is a deceptive advertisement, to promulgate appropriate orders forbidding it, and to commence execution proceedings. ${ }^{80}$ The fact-finder con-

54. 498 F.2d at 440 n.4.

55. Id. at 443.

56. See note 53 supra.

57. Only if an agency order were to proscribe "all deceptive advertising" would the court be forced to decide in the first instance whether a particular representation was "deceptive." An order that broad might well be judicially unenforceable. See FTC v. Henry Broch \& Co., 368 U.S. 360, 367-68 (1962) (orders inust be "sufficiently clear and precise" to avoid raising serious questions as to their meaning and application).

58. The validity of a cease and desist order is not reviewable in an execntion action. See FTC v. Morton Salt Co., 334 U.S. 37, 54 (1948); Farmington Dowel Prods. v. Forster Mfg. Co., 421 F.2d 61, 75 (1st Cir. 1970).

59. FTC Cease and Desist Order, Noveinber 27, 1967, quoted in United States v. J.B. Willians Co., Inc., 354 F. Supp. 521, 526 (S.D.N.Y. 1973), aff'd in part, rev'd in part, $498 \mathrm{~F} .2 \mathrm{~d} 414$ (2d Cir. 1974). When an order is broadly phrased to preclude indirect or inplied representations, as was the case in Williams, the issue for the court will be whether the challenged advertising can fairly be said to convey the same impression as that expressly proscribed. While this is a highly subjective inquiry, it is not one which denuands the attention of coininnnications experts.

60. See Holloway v. Bristol-Myers Corp., 485 F.2d 986 (D.C. Cir. 1973); United States v. St. Regis Paper Co., 355 F.2d 688 (2d Cir. 1966), both discussed in note 53 supra. 
siders the "meaning" of the representation only for the purpose of determining whether it falls within the forbidden territory. ${ }^{61}$ Yet, plenary proceedings preclude the agency from unilaterally construing its own orders so as to find violations and from acting as judge as well as prosecutor in essentially ex parte actions to impose penalties. ${ }^{62}$ The statute establishes the courts as the impartial arbiters to determine how far an order can legitimately be stretched when the agency seeks to apply it to new conduct which the order fails to specifically proscribe.

\section{Standards for Granting Summary Judgment}

A defendant's right to plenary proceedings in a civil penalty action is limited by the district court's power to grant summary judgment in favor of the government if it finds no genuine issues of material fact. ${ }^{83}$ In this respect a statutory penalty suit is like any other civil action, and the case law interpreting the availability of summary judgment under rule $56^{64}$ is directly applicable. A party opposing such a motion is entitled to "the benefit of all reasonable doubts in determining whether a genuine issue exists." ${ }^{65}$ But he must be able to produce soine plausible documentary evidence to support his contentions or tisk being demied a full trial. ${ }^{86}$

61. See United States v. Hindman, 179 F. Supp. 926 (D.N.J. 1960), where the finder of fact was to decide whether the purchasers of military uniforms would think that the label "custom-tailored" meant the same thing as "custonl-made," the latter label expressly forbidden by an FTC cease and desist order. The Commission had set the standard (by ruling that "custom-made" was deceptive); it remained for the jury only to apply that standard to the facts of the case.

In neither Williams nor Hindman was there any inquiry into whether anyone was actually deceived by the advertising at issue. The Williams court noted that "the FTC did not have the burden [i $m$ the execution action] of showing that the accused cominercials, if within the order, were false and deceptive . . . " 498 F.2d at 431.

62. Id. at 429.

63. See FED. R. Crv. P. 56. On a motion for summary judgment, the court does not try issues of fact; it merely determines whether there are such issues which must be tried. If it finds no such issues, it may award a judgment to the moving party as a matter of law. See C. Wright, HANDBOOK ON THE LAW OF FEDERAL COURTS 44143 (2d ed. 1970). The party opposing the motion, however, has a right to a full evidentiary hearmg on all genuine issues of material fact. This includes the right to call his own witnesses and to cross-examine his opponent's witnesses, rather than having to rely solely on affidavits to state his case. See Hanley v. Chrysler Motors Corp., 433 F.2d 708, 711 (10th Cir. 1970); Hycon Mfg. Co. v. H. Koch \& Sons, 219 F.2d 353, 355 (9th Cir.), cert. denied, 349 U.S. 953 (1955); Colby v. Klune, 178 F.2d 872, 873-74 (2d Cir. 1949).

64. Fed. R. Civ. P. 56.

65. C. WRIGHT, supra note 63 , at 443 .

66. He cannot, as one federal court said in a civil penalty suit, create such an issue "simply by saying over and over that one exists." United States v. Beatrice Foods Co., 344 F. Supp. 104, 111 (D. Minn. 1972), aff'd, 493 F.2d 1259 (8th Cir. 1974). 
In his Williams dissent, Judge Oakes maintained that the usual standards for summary judgment are not appropriate in a civil penalty proceeding because, as he viewed it, that action is simply a form of judicial review. ${ }^{07}$ Judge Oakes seemingly agreed with the government that a summary judgment is proper whenever the challenged advertising had any "tendency ... . to represent by implication any claim that is prohibited by the [agency] order, even though this implication may be drawn by only a small part of the public . . . ."08 This standard finds some support in the case law ${ }^{09}$ once the premise is accepted that a civil penalty action is analogous to judicial review of an agency order. But if, as this Note has suggested, a plenary trial is required in such actions, the standard is clearly inappropriate. ${ }^{70}$ Its application would, in effect, transform the proceedings into judicial review by allowing the court to render judgment for the government on a showing of any evidence that its order might have been violated. The defendant's right to plenary proceedings in which he could call and cross-

67. See notes 26-28 supra and accompanying text.

68. Brief for Appellee at 31, United States v. J.B. Williams Co., Inc., 498 F.2d 414 (2d Cir. 1974). For Judge Oakes' discussion of this standard, see $498 \mathrm{~F} .2 \mathrm{~d}$ at 458.

The government went one step further in its brief, contending that "if any of the advertisements are ambiguous, and capable of being read either as violating the order or not violating the order, they should be construed as falling within the prohibition of the order." Brief for Appellee at 32, United States v. J.B. Williams Co., Inc., 498 F.2d 414 (2d Cir. 1974), citing United States v. 95 Barrels of Vinegar, 265 U.S. 438, 443 (1924), FTC v. Sterling Drug Co., 317 F.2d 669, 675 (2d Cir. 1963), Kalwajtys v. FTC, 237 F.2d 654 (7th Cir. 1956), cert. denied, 352 U.S. 1025 (1957), and Rhodes Pharmacal Co., Inc. v. FTC, 208 F.2d 382, 387 (7th Cir. 1954), rev'd on other grounds, 348 U.S. 940 (1955). These cases, however, are questionable precedent for such a weak summary judgment standard. Both the Rhodes and Kalwajtys courts were enunciating the proper standard for upholding agency findings in judicial review proceedings, and even they conceded that the meaning of advertisements and their tendency to mislead are questions of fact. 208 F.2d at 387; 237 F.2d at 656. Iu 95 Barrels and Sterling Drug, the courts paid lip service to the proposition that any "tendency" to mislead may constitute a violation, but refused summary judgment and examined this tendency as an issue of fact.

69. See, e.g., Aronberg v. FTC, 132 F.2d 165, 167 (7th Cir. 1942), cited in United States v. J.B. Williams Co., Inc., 498 F.2d 414, 458 (2d Cir. 1974) (Oakes, J., dissenting). Aronberg, a circuit court proceeding to review the validity of an FTC cease and desist order, favored a weak summary judgment standard in the interest of protecting even the most ignorant consumer. 132 F.2d at 167. Aronberg, however, was not considering the summary judgment standard appropriate in a de novo trial, but rather the minimum showing necessary to uphold an agency order on review.

70. It may be perfectly proper in a review proceeding, conducted according to the substantial evidence rule, to affirm the agency's definition of deceptive advertising whenever such advertising has "any tendency" to mislead a "small part of the public." But it would make little sense to employ the same standard to grant summary judgment in an independent judicial action to assess potentially massive penalties where the issue is whether a particular course of conduct violated a cease and desist order and where the agency's decision in that regard is entitled to no special weight. 
examine witnesses and perhaps have disputed facts determined by a jury would be largely nullified.

It is essential, then, if civil penalty suits are to be conducted as independent plenary trials, to insist that the requirements of rule 56 be strictly observed in any award of summary judgment. The standard employed inust be strict enough to require the inoving party to establish through his affidavits, unaided by deference or inference, that there exist no genume issues of material fact and that he is entitled to judgment as a inatter of law. All inferences drawn from the affidavits in support of summary judgment "must be viewed in the hight most favorable to the party opposing the motion."71 Any lesser standard would permit use of the summary judgment as a means of circumventing the statutory requirement of a plenary trial and would accord to the agency's decisions a weight which they would not carry in that trial.

Because the grant of summary judgment must ultimately depend upon the facts of each individual case, it is difficult to suggest any specific guidelines that the courts should follow in civil penalty actions. Application of the normal standard is made particularly difficult in inost cases involving deceptive advertising because of the subtlety of having to determine whether a triable issue is posed by advertisements whicl allegedly inake, indirectly or by implication, claims prohibited by a cease and desist order. ${ }^{72}$ Nevertheless, it may be instructive to examine a few of the civil penalty cases which have considered the summary judgment issue.

71. United States v. Diebold, Inc., 369 U.S. 654, 655 (1962). Moreover, recent expressions of the Supreme Court have suggested that there are "sharper limitations on the use of summary judgment" in cases where the seventh amendment guarantees a jury trial. Weinberger v. Hynson, Westcott \& Dunning, Inc., 412 U.S. 609, 621-22 (1973), citing Adickes v. Kress \& Co., 398 U.S. 144, 153-61 (1970), and White Motor Co. v. United States, 372 U.S. 253 (1963).

72. The availability of summary judgment in favor of the government may depend on the specificity of the agency order which has allegedly been violated. "II]t [is] reasonable for the Commission to frame its order[s] broadly enough to prevent respondents from engaging in . . . illegal practices in future advertisements," similar, but not identi$\mathrm{cal}$, to those found objectionable at the time the order is promulgated. FTC v. ColgatePalmolive Co., 380 U.S. 374, 395 (1965); see FTC v. Ruberoid Co., 343 U.S. 470, 473 (1952); NLRB v. Express Publishing Co., 312 U.S. 426, 436-37 (1941). Accordingly, the agency may formulate an order, as it did with respect to Geritol, prohibiting any advertisement "which represents directly or by implication that the use of such preparation will be beneficial in the treatment or relief of tiredness, loss of strength . . . ." 354 F. Supp. at 526 . See note 59 supra. Such an order, unlike one simply precluding direct claims that Geritol will relieve tiredness or specifically outlawing the use of the word "power," leaves considerable room for dispute over whether a specific representation carries the forbidden implication. If the defendant can offer any meaningful evidence that it does not, summary judgment must be denied, 
In Williams, the appellate court found summary judgment to be inappropriate on all but two counts. ${ }^{73}$ The Government had charged that references to "blood building power" and the juxtaposition of sad and happy subjects in Geritol commercials conclusively implied to viewers that the preparation was an effective remedy for tiredness and thus violated the FTC's order. The court observed, however, that while this might be a possible inference, it was "not one that a jury would be compelled to draw." "In fact, the majority found the claim that Geritol builds "iron power" in the blood to be "so far from a representation that it is a generally effective remedy for tiredness that the Commission's objections . . . seem[ed] rather baseless." "75

The summary judgment question was closer in United States $v$. Hindman, ${ }^{76}$ where the Government contended that labeling military uniforms "custom-tailored" unquestionably violated an FTC order forbidding any direct or indirect representation that the uniforms were "custom-made." But when the defendant offered some proof that the new language, as applied to military uniforms, meant something different to the average purchaser from the proscribed terms, the court ruled that he should have the chance to present his evidence at trial and refused to grant summary judgment. ${ }^{77}$

The cases where summary judgment has been granted, however, indicate that the courts are responsive to obvious attempts by advertisers to circumvent the strictures of a cease and desist order. In fact, the use of summary judgment seems to have been confined largely to the situation where a defendant, whose advertising had been attacked by a cease and desist order, did not materially alter his deceptive representations and therefore had hittle ground for arguing that his conduct was not proscribed by the agency's order. ${ }^{78}$

73. See notes 16,19 supra.

74. $498 \mathrm{~F} .2 \mathrm{~d}$ at 433.

75. Id. at 432. The court even suggested that summary judgment in favor of J.B. Williams on that issue might be appropriate. Id. at 433.

76. 179 F. Supp. 926 (D.N.J. 1960). See notes $99-100$ infra and accompanying text for further discussion of Hindman.

77. Id. at 928.

78. This was the case in United States v. Vulcanized Rubber \& Plastics Co., 178 F. Supp. 723 (E.D. Pa. 1959), affd, 288 F.2d 257 (3d Cir.), cert. denied, 368 U.S. 821 (1961), where the defendant changed the labels on his counbs from "rubber" to "rubber resin," and in United States v. Piuma, 40 F. Supp. 119 (S.D. Cal. 1941), aff'd, 126 F.2d 601 (9th Cir.), cert. denied, 317 U.S. 637 (1942), where the defendant switched from advertising a "gland tonic" to advertising a "gland tablet." The FemIron charges in Williams, see notes 16, 19 supra, provide a further illustration. The court held first that the defendants had failed to furnish any meaningful evidence that FemIron was not a preparation "substantially similar" to Geritol and therefore not included within the original cease and desist order. 498 F.2d at 431 . It noted that the only difference in the two 
Thus, the conventional standard for awarding summary judgment does not impose such a severe burden that it will enable an advertiser to obtain a full trial every time it makes an insignificant change in its product or representation in an effort to avoid the exphicit proscriptions of a cease and desist order. Summary judgment can and does serve as a necessary safety valve to prevent unwarranted delay and frustration in the execution of agency orders. And, if properly apphed, it can do so without jeopardizing the plenary proceedings for genuine factual disputes that an independent civil penalty action is intended to provide.

\section{Is THERE A Right to Trial By JuRY?}

Assuming that plenary proceedings are required in civil actions for the violation of administrative cease and desist orders, the question then becomes whether there is a corresponding right to trial by jury. The court in Williams considered this question for the first time at the circuit court level and properly concluded that there is such a right whenever there are disputed issues of material fact. ${ }^{79}$

The basis for asserting this right in such proceedings is Federal Rule of Civil Procedure 38(a), which preserves inviolate "[t]he right of trial by jury as declared by the Seventh Amendment to the Constitution or as given by a statute of the United States . . . ."80 The seventh amendment, in turn, "preserves" the right of jury trial in all significant "suits at common law."81 Simce most regulatory legislation, including the FTCA, does not specifically provide for jury trials in civil penalty actions, ${ }^{82}$ parties to such suits inust rely on the general guarantees of the seventh amendinent.

The question of what constitutes a suit at common law has been the subject of nuch debate and litigation. ${ }^{83}$ The Supreme Court has

products was one of dosage and that the order could not be avoided "simply by a process of dilution and relabeling." Id. And, once FemIron was found to be covered by the order, there was little difficulty im approving summary judgment as to violation of the order as well since the FemIron commercials carried the "plain implication" that the product would relieve tiredness. Id. at 434 .

79. 498 F.2d at $421-30$.

80. FED. R. Crv. P. 38(a).

81. The seventh amendinent provides: "In Suits at common law, where the value in controversy shall exceed twenty dollars, the right of trial by jury shall be preserved . . . " U.S. Const. amend. VII.

82. See, e.g., FTCA $\S \S 5(l), 16,15$ U.S.C. $\S \S 45(l), 56$ (Supp. 1974), amended by Pub. L. No. 93-637 $\$ 204$ (a) (Jan. 4, 1975), reprinted in 4 TRADE REG. ReP. T 25,268 (quoted in note 7 supra), which speaks only of a "civil action." See also statutes cited in note 24 supra. But see Federal Communications Act, 47 U.S.C. $\$ \$ 503-04$ (1970).

83. See generally James, Right to a Jury Trial in Civil Actions, 72 YAlE L.J. 655 . 
construed the language of the seventh amendment to require jury trials only in actions which were triable under common law rules as they existed in England at the time the amendment was enacted in $1791 .^{84}$ Yet, this interpretation has not precluded application of the amendment to newly created rights of a legal nature. ${ }^{85}$ It is now well settled that the amendment guarantees the availability of a jury trial in a cause of action based on a statute if the statutory rights are enforceable in essentially legal proceedings in an ordinary court of law. ${ }^{86}$ Where Congress, in creating a new right of action, has not expressly stated what the mode of trial should be, ${ }^{87}$ the traditional approach has been to analogize the cause of action to its historical counterpart at law or in equity for the purpose of determining whether there is a right of jury trial. ${ }^{88}$ While the Supreme Court has suggested that the focus should be upon "the nature of the issue to be tried rather than on the character of the overall action"89 and has expanded somewhat the factors to be evaluated, ${ }^{00}$ the primary consideration remains the treatment accorded

(1963); McCoid, Right to Jury Trial in the Federal Courts, 45 Iowa L. Rev. 726 (1960).

84. See Galloway v. United States, 319 U.S. 372, 388 (1943); Baltimore \& Carolina Line, Inc. v. Redman, 295 U.S. 654, 657 (1935); Dimick v. Schiedt, 293 U.S. 474, 487 (1935).

85. In Ross v. Bernhard, 396 U.S. 531 (1970), the Supreme Court noted:

The Seventh Amendment preserves to litigants the right to jury trial in suits at common law-"not merely suits which the common law recognized among its old and settled proceedings, but suits in which legal rights were to be ascertained and determined, in contradistinction to those where equitable rights alone were recognized, and equitable remedies were administered .... In a just sense, the amendment then may well be construed to einbrace all suits which are not of equity and admiralty jurisdiction, whatever may be the peculiar form which they may assume to settle legal rights." Id. at 533, quoting Parsons v. Bedford, 28 U.S. (3 Pet.) 433, 447 (1830).

See Pernell v. Southall Realty, 416 U.S. 363, 374-76 (1974); Curtis v. Loether, 415 U.S. 189, $194-96$ (1974); 5 J. MOORE T 38.08[S], at 79-80.

86. See Pernell v. Southall Realty, 416 U.S. 363, 374-76 (1974); Curtis v. Loether, 415 U.S. 189, 194 (1974). See also Hepner v. United States, 213 U.S. 103, 115 (1909). But cf. NLRB v. Jones \& Laughlin Steel Corp., 301 U.S. 1, $48-49$ (1937).

87. There is little doubt that Congress, having created new statutory rights and obhgations, can provide for their adjudication by jury trial in situations where the seventh amendment would not require it. See Michaelson v. United States, 266 U.S. 42, 64-67 (1924) (Clayton Act provision granting jury trial in certain contempt proceedings); The Genesee Chief v. Fitzhugh, 53 U.S. (12 How.) 443, 460 (1851) (provision for jury trial in admiralty actions growing out of act extending jurisdiction of federal district courts over navigation on Great Lakes); 5 J. MOORE \ 38.11[4], at 115-17.

88. See Luria v. Unitcd States, 231 U.S. 9, 27-28 (1913); 5 J. Moore If 38.11[7], at 128.4. See generally James, supra note 83, at 657-64.

89. Ross v. Bernhard, 396 U.S. 531,538 (1970).

90. In Ross v. Bernhard, 396 U.S. 531 (1970), the Supreme Court, in considering the seventh amendment right to jury trial in a shareholder's derivative suit, declared: "[T] tom with reference to such questions; second, the remedy sought; and, third, the practical abilities and limitations of juries." Id. at 538 n.10. 
similar actions prior to the merger of law and equity. Suits which fall within the well recognized forms of action at common law must be tried to a jury if a party so requests. ${ }^{21}$

This application of the seventh amendment effectively eliminates any constitutional right to a jury trial in two of the available types of civil actions to execute administrative orders. Neither contempt proceedings $^{92}$ nor suits for equitable rehef ${ }^{93}$ were triable to a jury at common law. The civil penalty action, however, is significantly different. The recovery of a monetary award in a civil penalty proceeding in a court of law would seem to be a predominantly legal action in the nature of a suit at common law. Indeed, this appears to be the view of most authorities. Professor Moore, for example, has observed that "there is a right of jury trial when the Umited States sues . . . to collect a penalty, even though the statute is silent on the right."94 A number of cases decided in the early 1900's equated an action to recover a statutory civil penalty with the common law action of debt, which was triable to a jury. ${ }^{95}$ More recent decisions have reached the same result

91. See Pernell v. Southall Realty, 416 U.S. 363 , 375 (1974); 5 J. MOORE If 38.11 [5], at 118.

92. See Shillitani v. United States, 384 U.S. 364, 368-71 (1966). Recent cases, however, have distinguished between the jury trial right in criminal contempt proceedings, i.e., where the object is to penalize the defendant for violation of a court order regardless of his subsequent compliance, and civil contempt proceedings, where the object is reniedial and punishment continues only so long as the defendant rentains in violation. See id.; Cheff v. Schnackenberg, 384 U.S. 373, 377-78 (1966). In Bloon1 v. Illniois, 391 U.S. 194, 198 (1968), the Suprenie Court held that cases of "serious" criminal contentpt (generally, where the penalty may exceed six nionths imprisonment) are triable to a jury. The Court left standing, however, the decision in Shillitani that civil contempt does not justify a jury trial and the holding in Cheff that a jury is not required in criminal proceedings where the contempt is treated as a petty offense. Id. Since a contempt action for violation of a court-enforced administrative order, even if criminal in nature, is unlikely to involve penalties in excess of six months imprisonment, it will be rare that such an action will be triable to a jury. See Cheff v. Schnackenberg, 384 U.S. 373, 377-79 (1966).

93. See Katchen v. Landy, 382 U.S. 323, 336-37 (1966); United States v. Louisiana, 339 U.S. 699, 706 (1950); Shields v. Thomas, 59 U.S. (18 How.) 253, 262 (1855).

94. 5 J. MOore If 38.31[1], at 232-33, cited in United States v. J.B. Williams Co., Inc., 498 F.2d 414, 422-23 (2d Cir. 1974).

95. See United States v. Regan, 232 U.S. 37, 47 (1914); Hepner v. United States, 213 U.S. 103, 108 (1909). In both cases, the government sued in federal court to recover a nronetary penalty for violation of the immigration laws. The Court found the actions to be civil in nature and observed that the defendant was entitled to have the issues tried before a jury. 232 U.S. at $47 ; 213$ U.S. at 115. See also United States v. Jepson, 90 F. Supp. 983, 986 (D.N.J. 1950).

Judge Oakes, in his Williams dissent, found this line of cases to be inapposite because "in none of them was there a prior administrative proceeding culminating in a judicially upheld adninistrative order, the violation of which was in issue." 498 F.2d at 451 . This argument reflects the importance that Judge Oakes attached to administra- 
simply on the basis that a civil penalty action is predominantly legal in nature. ${ }^{96}$ And it has consistently been held that the closely analogous statutory forfeiture proceeding ${ }^{97}$ is a civil action at law in which a jury trial is available on demand. ${ }^{88}$

In addition, United States $v$. Hindman, ${ }^{99}$ the only reported decision prior to Williams which squarely faced the issue of whether there is a right to a jury trial in a civil penalty suit for violation of an FTC cease and desist order, concluded that a jury trial was appropriate. The defendant in Hindman was accused of imdirectly violating a cease and desist order by using labels on military uniforms which imphed that which was proscribed by the order. The court held that it was necessary to permit the jury to decide the factual question of what the labels imphied to the average consumer of the product and whether that implication was forbidden by the order. ${ }^{160}$

tive hearings preceding an execution suit. See id. at 439 . See note 27 supra. But if a plenary trial is required in any case, and the agency findings are entitled to no special weight, see notes 30-40 supra, Hepner and its progency would seem every bit as relevant to the right of jury trial as cases preceded by administrative hearings.

96. See Connolly v. United States, 149 F.2d 666 (9th Cir. 1945) (penalty under 25 U.S.C. $\S 179$ (1970) for illegal use of Indian lands); United States v. Beatrice Foods Co., 344 F. Supp. 104 (D. Minn. 1972), aff'd, 493 F.2d 1259 (8th Cir. 1974) (penalty under section $5(l)$ of the FTCA for violation of consent order); United States ex rel. Rodriguez v. Weekly Publications, 9 F.R.D. 179 (S.D.N.Y. 1949) (penalty for making false claim against government).

97. Many civil penalty statutes, like section $5(l)$ of the FTCA, are worded in terms of forfeiture. Section $5(l)$ provides that a violator shall "forfeit and pay to the United States a civil penalty." 15 U.S.C.A. $\$ 45(l)$ (Supp. 1974) (emphasis added).

98. See 443 Cans of Frozen Egg Prod. v. United States, 226 U.S. 172, 183 (1912); United States v. Winchester, 99 U.S. 372, 374 (1878).

99. 179 F. Supp. 926 (D.N.J. 1960). See text accompanying notes 76-77 supra for a discussion of the facts of Hindman and of the summary judgment standard applied therein.

100. The Hindman court noted that if the term used on the labels meant substantially the same thing to the average purchaser as the forbidden term, a violation would exist. But the nueaning of the representations nuade, it observed, "is not the neaning which would be attached to them by experts, but by the average man who would be likely to purchase the articles in question and to whom those representations were made." Id. at 928.

The Hindman opinion drew severe criticism in United States v. Vulcanized Rubber \& Plastics Co., 288 F.2d 257 (3d Cir.), cert. denied, 368 U.S. 821 (1961), a subsequeut civil penalty case under the FTCA decided by the court of appeals of the same circuit. In Vulcanized Rubber, the court granted the government's motion for suminary judgment, rejecting Hindman (in dictum) on grounds (1) that the Hindman court should have linited its deliberations to whether or not the labeling there was within the proscription of the FTC order and not whether it was deceptive and (2) that allowing a jury to determine the meaning of the representations would usurp the function of the FTC. $I d$. at $258 \mathrm{n} .2$. This criticism is of questionable validity, and, as the majority suggested in Williams, see 498 F.2d at 422 , citing L. J JFFE 319 n.237, nlay have resulted from a misunderstanding of the district court's action. In the first place, the judge in 
Despite this precedent, however, it might be argued that a jury trial should be denied in coniplex civil penalty actions because of the jury's limited competence. ${ }^{101}$ Judge Oakes contended in his Williams dissent that no jury of laymen is qualified "to define and adjudicate what is or is not deceptive advertising"-a task that often involves the FTC in years of investigation, negotiations, hearings and litigation, and one which requires extensive resources and expertise to accomplish properly. ${ }^{102}$ But this argument rests on a misconception of the issue before the court. If, as this Note has suggested, the only question for the fact-finder is whether a particular advertisement has made, indirectly or by implication, the representation forbidden by a cease and desist order, ${ }^{103}$ there would seem to be little practical difficulty in allowing a jury to decide the result. Indeed, if the standard is to be the meaning conveyed to the average man, "who better than a lay customer to decide."104 As Judge Friendly noted in Williams, this kind of question is the "very sort which juries are traditionally called on to resolve." 105

\section{The Administrative Proceeding Exception}

A possible exception to the constitutional right to trial by jury might be found in that carved out for essentially administrative proceedings. This exception apparently originated in NLRB v. Jones \& Laughlin Steel Corp., ${ }^{108}$ in which the Supreme Court refused to apply the seventh amendment to require a jury trial in an NLRB proceeding to determine an employer's liability for monetary back pay awards. The Court held, in essence, that such proceedings do not qualify as

Hindman clearly restricted the issue before the jury to that suggested by the Vulcanized Rubber court. Secondly, as this Note has already discussed, neither the judge nor the jurors are given free rein in a civil penalty action to determine whether a given course of conduct is inconsistent with the purpose of the FTCA, but they are limited to determining whether the alleged conduct violates the pre-existing agency order.

101. In Ross v. Bernhard, 396 U.S. 531 (1970), the Supreme Court suggested that one factor to be considered in determining whether a jury trial is constitutionally required is "the practical abilities and limitations of juries." Id. at 538 n.10. See note 90 supra for the other factors involved.

102. 498 F.2d at 452 .

103. See notes 53-62 supra and accompanying text.

104. L. JAFFE $319 \mathrm{n} .237$ (approving the use of a jury in Hindman).

105. 498 F.2d at 429 . While conceding that the question of what a particular advertisement implies may be inore difficult to resolve than the simpler issues of how, when, and where an advertiseinent was disseminated, id., Judge Friendly noted that "when there is a right to a jury trial, it extends to all kinds of questions of fact, not simply to soine." Id. n.16.

106. 301 U.S. 1 (1937). 
suits at common law. ${ }^{107}$ This conclusion retains contemporary validity, as evidenced by recent statements of the Supreme Court. ${ }^{108}$ It has enabled Congress to delegate to the regulatory agencies the quasi-judicial power to adjudicate newly created statutory rights which have no ready counterpart at common law and to impose civil penalties through their own administrative processes with no more than limited judicial review. ${ }^{108}$

The Supreme Court has made it clear, however, that the exception for admimistrative proceedings is a narrow one. In Curtis v. Loether ${ }^{110}$ the Court observed that:

Jones \& Laughlin merely stands for the proposition that the Seventh Amendment is generally inapplicable in administrative proceedings, where jury trials would be incoinpatible with the whole concept of administrative adjudication and would substantially interfere with the [agency's] role in the statutory scheme. ${ }^{111}$

\section{But the Court contmued:}

[W] hen Congress provides for enforcement of statutory rights in an ordinary civil action in the district courts where there is obviously no functional justification for denying the jury trial right, a jury trial must be available if the action involves rights and remedies of the sort typically enforced in an action at law. ${ }^{112}$

Judge Oakes argued in Williams that to allow a jury of laymen to determine the meaning of an allegedly deceptive advertisement is "incompatible with the whole concept of administrative adjudication," "substantially interfere[s] with the [agency's] role,"113 and thus provides a "functional justification for denying the jury trial right."114 However, as has been previously suggested, allowing a court to perforin the limited task-that of determining whether an advertisement represents what has been proscribed by an FTC cease and desist order-

107. Id. at 48-49; cf. Block v. Hirsch, 256 U.S. 135, 158 (1921).

108. See Pernell v. Southall Realty, 416 U.S. 363,383 (1974) (dictum); Curtis v. Loether, 415 U.S. 189, 194 (1974) (dictum); cf. Katchen v. Landy, 382 U.S. 323 (1966) (approving summary proceeding without a jury in bankruptcy actions).

109. See note 21 supra and accompanying text.

110. 415 U.S. 189 (1974). Curtis recognized a seventh amendment right of jury trial in a civil action brought by private plaintiffs in the federal courts under section 812 of the Civil Rights Act of 1968, 42 U.S.C. $\$ 3612$ (1970), to recover damages for violation of the Act's fair housing provisions.

111. 415 U.S. at 194 (emphasis added; footnotes omitted).

112. Id. at 195 (emphasis added); accord, Pernell v. Southall Realty, 416 U.S. 363, 383 (1974).

113. 498 F.2d at 452, quoting Curtis v. Loether, 415 U.S. 189, 194 (1974).

114. 498 F.2d at 453 . 
does not usurp the primary responsibilities of the FTC. ${ }^{115}$ Moreover, characterizing the independent judicial action required for the imposition of civil penalties as an "administrative proceeding" is inconsistent with the commonly understood meaning of those terms. It is difficult to contend that, in fact, this is not a case where "Congress provide[d] for enforcement of statutory rights in an ordimary civil action in the district courts."116 The demial of a jury trial in the NLRB proceedings in Jones \& Laughlin ${ }^{117}$ is inapposite because in that case the agency itself was assigned the adjudicative responsibility; in civil penalty proceedings the agency is denied that authority. On the contrary, the power to determine conclusively that an administrative order has been violated is vested by the FTCA and other statutes exclusively in the district courts. If genuine issues of fact exist, they must be committed to a jury on demand.

\section{What About the Sixth Amendment?}

An alternate route to finding a right of jury trial in statutory penalty suits for the violation of administrative orders might be through the sixth amendment guarantee of trial by jury in all criminal proceedings. Beheving that well-established precedent did not permit the FTC execution proceeding to be characterized as "criminal" in nature, the Williams court quickly disposed of the possibility that the sixth amendment would be apphicable. ${ }^{118}$ Nevertheless, the argument for applying the sixth amendment in this context has inore merit than the Williams court was willing to concede.

In Williams, the court rehed primarily on the fact that Congress, in drafting the FTCA, had expressly characterized the penalty suit as "civil."119 But, it is well settled that "the legislature cannot, by a mere change of name or form, convert that which is in its nature a criminal prosecution into a civil proceeding and thus deprive the parties of their rights to a trial by jury." ${ }^{120}$ Under the Supreme Court's more recent

115. See notes 53-62 supra and accompanying text.

116. Curtis v. Loether, 415 U.S. 189, 195 (1974).

117. See notes 106-07 supra and accompanying text.

118. 498 F.2d at 421.

119. According to the majority opinion in Williams: "When Congress has characterized the remedy as civil and the only consequence of a judgment for the Government is a mouey penalty, the courts have taken Congress at its word." Id.; see Helvering v. Mitchell, 303 U.S. 391, 399 (1938).

120. Ashly v. Wait, 228 Mass. 63, 70, 116 N.E. 961, 966 (1917), appeal dismissed per curiam for want of jurisdiction, 250 U.S. 652 (1919); accord, Trop v. Dulles, 356 U.S. 86, 94-96 (1958); United States v. Constantine, 296 U.S. 287, 294 (1935). The Williams court recognized this restriction: "Congress could not permissibly undermine 
decisions, it is the purpose of the statute and the nature of the remedy that must determine whether an action is civil or criminal. ${ }^{121}$ The ultimate question is whether the sanctions provided are designed to be punitive, i.e., to punish violators and deter future wrongdoing, or whether they are intended to serve a purely remedial purpose by compelling a recalcitrant party to cease present violations or to compensate for the injuries he has caused. ${ }^{122}$

While the sanctions prescribed by the civil penalty provision of the FTCA do not threaten imprisonment of offenders, the potential monetary penalties can be substantial. ${ }^{123}$ The precedent which has construed such penalties as civil ${ }^{124}$ may be questioned in light of the increased magnitude of possible penalties. ${ }^{125}$ There is hittle doubt that such severe penalties carry a substantial deterrent effect. Certainly, they bear no relation to the extent of imjury caused, nor are they used to compensate victims of the illegal conduct. ${ }^{126}$ And, while they may

constitutional protections simply by appending the 'civil' label to traditionally criminal provisions," 498 F.2d at 421 , but it nevertheless seemed to place substantial weight on the legislative characterization.

121. See Shillitani v. United States, 384 U.S. 364, 368-71 (1966) (conteinpt); One 1958 Plymouth Sedan v. Pennsylvania, 380 U.S. 693, 701 (1965) (forfeiture); Kennedy v. Mendoza-Martinez, 372 U.S. 144, 167-69 (1963) (deportation); Trop v. Dulles, 356 U.S. 86, 94-96 (1958) (deportation).

122. See authorities cited in note 121 supra.

123. For example, the district court assessed $\$ 812,000$ in penalties against J.B. Williams and its advertising subsidiary. United States v. J.B. Williams Co., Inc., 354 F. Supp. 521 (S.D.N.Y. 1973), aff'd in part, rev'd in part, 498 F.2d 414 (2d Cir. 1974). Although the Second Circuit subsequently found it inappropriate to award duplicate penalties against the two commonly owned companies, see 498 F.2d at 436-37, the effect would be little different today in light of the fact that penalty amounts have since been doubled by a statutory amendment. See note 125 infra.

124. See, e.g., Helvering v. Mitchell, 303 U.S. 391, 398-405 (1938); Hysner v. United States, 213 U.S. 103, 108 (1909).

125. In late 1973, section $5(l)$ of the FTCA was amended to increase the penalty for each violation of an FTC order from $\$ 5000$ to $\$ 10,000$. See 15 U.S.C.A. $\$ 45(l)$ (Supp. 1974). In Williams, the Second Circuit affirmed the right of the FTC to characterize each separate broadcast of an impermissible commercial as a separate violation. 498 F.2d at 435-36.

The Williams court failed to consider the relevance of the size of the judgunent as it related to the criminal nature of the penalties, observing that the only issue presented was whether the trial court had abused its discretion in assessing the penalty. Id. at 438.

126. It has been suggested that such penalties serve to compensate the government for its expenses of enforcement, see United States v. Alcatex, 328 F. Supp. 129, 13233 (S.D.N.Y. 1971), but the penalties involved in cases like Williams are considerably greater than the government's expense in bringing the suit. Moreover, the FTCA now includes specific provisions making conipensatory rehef available for consuiners through rescission of contracts, refund of money, noney damages, etc. Pub. L. No. 93-637, § 206(a) (Jan. 4, 1975), reprinted in 4 Trade Reg. REP. If 25,271. Presumably, these 
be useful in terminating present violations, they are imposed regardless of the offender's subsequent compliance. ${ }^{127}$

Applying the Supreme Court's test, the purpose of this remedy seems predominantly punitive and suggests that the statutory penalty proceedings here at issue could, with little difficulty, be cliaracterized as criminal in nature. In light of the Court's recent willingness to extend the right of jury trial into new areas, ${ }^{128}$ it may ultimately develop that the right to a jury trial in an FTC execution proceeding is based on the sixth amendment instead of the seventh. ${ }^{129}$

\section{CONCLUSION}

With the decision in United States v. J.B. Williams Co. and the recent amendments to the FTCA, the role of the courts in proceedings to execute FTC cease and desist orders lias been brought into sharper focus. The civil penalty action authorized by the FTCA can be viewed as a trial de novo on the question of whether a violation has occurred. ${ }^{130}$ Furthermore, where an execution action presents disputed issues of material fact, the parties are guaranteed a trial by jury. ${ }^{131}$

remedies will prove to be a substautial deterrent to wrongdoing as well as a means for compensating those injured, yet the civil peualty provisious have been retained. Why, if not to be used to penalize?

127. In Williams, for example, the company agreed to discontinue the use of commercials the FTC found objectiouable as soon as it was notified of the objection. See 498 F.2d at 419-20. None of the commercials in question had been broadcast for months wheu the government filed its complaint in district court. See id. at 418, 420-21.

128. See, e.g., Bloom v. Illimois, 391 U.S. 194 (1968) (criminal contempt); Kennedy v. Mendoza-Martinez, 372 U.S. 144 (1963) (deportation).

129. While a sixth amendment right would do no more than furnish an alternate source of protection in those judicial actions where the seventh amendment currently requires a jury trial, it would be crucial to obtaining a jury in those penalty proceedings now committed solely to the agencies for adjudication, see note 21 supra, and falling within the administrative proceeding exception to the seventh amendment. See notes 106-17 supra and accompanying text.

130. The conclusions of this Note as to the requirement for independent plenary proceedings in statutory civil peualty actions would seem fully as valid for other judicial actious to execute administrative orders. In contempt, forfeiture, and condemnation actions, as well as suits for imjunctive relief, the statutes call for the same sort of independent execution action in the federal courts; only the remedy is different. Many of these proceedings have already been held to require de novo trials. See notes 43-52 supra.

131. Calvin J. Collier, General Counsel of the FTC, views the Williams opinion as most likely dispositive of the right to a jury trial under the FTCA. The agency has not appealed the decision and, according to Mr. Collier, has no present intent to relitigate the general jury requirement question in other circuits. Interview with Calvin J. Collier in Durham, N.C., Oct. 22, 1974. 
The FTC has not, however, been deprived of its reason for existence. It is still solely responsible for interpreting the regulatory statutes, for formulating the standards and guidelines necessary to effectuate the law, and for promulgating orders commanding obedience to its interpretations. Even where the FTC must look to the judiciary for the ultimate execution of its orders, the courts are strictly limited in what they may consider. The order itself is beyond reexamination, and only the facts of its alleged violations may be freshly litigated.

Submitting the disputed issues of a penalty proceeding to a jury for decision does not meaningfully alter the FTC's execution process. Once the Commission is required to establish its case in plenary proceedings, ${ }^{132}$ the empaneling of a jury, rather than a judge, as trier of fact would seem to make little difference. Whatever additional delays in adjudicating violations and imposing sanctions ${ }^{133}$ may occur because a jury trial is required are not of sufficient weight to offset the alleged violator's constitutional right to a jury trial.

132. According to the FTC's General Counsel, summary judgment has been the exception rather than the rule in that agency's civil penalty actions, and bench trials have been customary, at lcast as to the facts of dissemmation of false advertising. Id.

133. It might seem that the grant of a jury trial is inordimately solicitous of the rights of an accused offender which has almost certainly had numerous opportunities to argue its case before the agency, to obtain interpretations of agency orders, and to voluntarily comply with them. But it will be a rare jury that is not immediately sympathetic toward a government agency bringing suit in the public interest on behalf of aggrieved citizens against a corporate defendant. And few corporations will be able to disregard an agency opinion that their conduct violates a valid order and risk the huge liabilities that could result if they are unable to vindicate themselves before the jury. 